\title{
Ser ou não ser armorial: uma enquete virtual
}

\author{
Marília P. Santos \\ Universidade Federal de Pernambuco \\ marilia_05030@hotmail.com \\ @mar_ilha.marilia
}

\begin{abstract}
Resumo: O Movimento Armorial foi estreiado em 18 de outubro de 1970. Ele tinha como objetivo criar uma arte "erudita" autenticamente brasileira, baseada no Barroco Ibérico e nas culturas populares do interior do Nordeste do Brasil. Foi liderado por Ariano Suassuna e composto por artistas e intelectuais do Nordeste. Após mais de 51 anos, seus ecos continuam aparecendo de várias formas nas cenas culturais, intelectuais e artísticas do país. E a música tem sido uma das expressões que mais se destaca. Entre 2015.2 e 2017.1 fiz uma pesquisa, com o objetivo de estudar e analisar as influências e repercussão do armorial na música "pernambucana" atual. Dentre os procedimentos metodológicos, realizei um questionário com ouvintes/receptores, para entender melhor a abrangência da música armorial e seus ecos. O objetivo desse trabalho é disponibilizar esse material dos/as ouvintes, para que estudiosos/as e pesquisadores/as possam utilizá-lo, pois no processo criativo o receptor é de fundamental importância.
\end{abstract}

Palavras-chave: Música, Música armorial, Etnomusicologia, Musicologia, Cultura popular.

\section{To be or not to be armorial: a virtual survey}

Abstract: The Armorial Movement was launched on October 18, 1970. Its objective was to create an authentically and "erudite" Brazilian art, based on the Iberian Baroque and popular cultures of the interior of Northeastern Brazil. It was led by Ariano Suassuna and composed of artists and intellectuals from the Northeast. After more than 51 years, its echoes continue to appear in various forms in the country's cultural, intellectual and artistic scenes. And music has been one of the expressions that stands out the most. Between 2015.2 and 2017.1 I did a research, with the aim of studying and analyzing the influences and repercussions of the armorial in current music of Pernambuco. Among the methodological procedures, I carried out a questionnaire with listeners/receivers, to better understand the scope of armorial music and its echoes. The objective of this paper is to make this material available to the listeners, so that scholars and researchers can use it, as in the creative process the receiver is of fundamental importance.

Keywords: Music, Armorial Music, Ethnomusicology, Musicology, Popular Culture.

\section{Introdução}

Na segunda metade do século XX, um grupo de artistas e intelectuais, liderado pelo escritor Ariano Suassuna, buscava criar uma arte "erudita" autenticamente brasileira, baseada no Barroco Ibérico e nas culturas populares do interior da região Nordeste do Brasil. Nasceu, então, em 18 de outubro de 1970, o Movimento Armorial (MORAES, 2000; NÓBREGA, 2000). Após mais de 51 anos seus ecos continuam aparecendo de várias formas nas cenas culturais, intelectuais e artísticas do país. E a música tem sido uma das expressões que mais tem se destacado.

Entre 2015.2 e 2017.1 fiz uma pesquisa de mestrado - Ecos Armoriais: influências e repercussão da Música Armorial em Pernambuco -, financiada pela CAPES, com o objetivo 
de analisar as influências e repercussão do armorial na música "pernambucana" atual. Dentre os procedimentos metodológicos, realizei entrevistas com alguns dos primeiros "criadores" da Música Armorial: Clóvis Pereira, Zoca Madureira, Antonio Nóbrega, e com artistas que fazem trabalhos com algum tipo de influência armorial: Antúlio Madureira, Sérgio Campelo, Fabiano Menezes, Dierson Torres, Nelson Almeida, Sérgio Ferraz. Para entender melhor a abrangência da música armorial e seus ecos, realizei um questionário com ouvintes/receptores.

A música é um fenômeno cultural e se manifesta de diversas maneiras nas sociedades (PINTO, 2001). Uma mesma sociedade pode ter inúmeros conceitos diferentes do que é música, todos convivendo juntos no mesmo ambiente, inclusive. Para compreender o que é e como aparecem os Ecos Armoriais encontrados na música produzida na atualidade é preciso saber como as pessoas a entendem, quais significados elas criam em torno dessa música, sejam aqueles advindos de quem a produz - composição e performance -, seja em relação a quem recebe - ouvintes.

Jean-Jacques Nattiez, ao falar do processo de criação e recepção da música em sua teoria tripartite, explica que o/a receptor/a projeta configurações simbólicas que são independentes do processo poiético. Este diz respeito à construção da obra, diferenciando-se do processo estésico, que só existe a partir de um processo de percepção que envolve o/a receptor/a (NATTIEZ, 1989, p. 17). O/A receptor/a nunca é apenas um agente passivo que recebe a obra tal como qual foi feita e projetada. Ele/a age sobre os significados que a constituem, criando, inclusive, outras configurações simbólicas.

O questionário realizado para compreender melhor como as pessoas têm entendido a música armorial foi feito por meio de uma rede social (Facebook). Ele foi enviado individualmente (inbox) para aproximadamente quinhentas pessoas, acompanhado por uma pequena explicação sobre a pesquisa e seus objetivos. Houve o retorno de noventa. Enumerei cada uma de acordo com o recebimento das respostas.

O objetivo desse trabalho é disponibilizar todo esse material dos/as ouvintes, para que outros/as estudiosos/as e pesquisadores/as também possam utilizá-lo. Foram realizadas duas perguntas: "O que é música armorial?" e "Você consegue perceber a influência desse tipo de música na atualidade?" 


\title{
O que é música armorial? (respostas das/os ouvintes)
}

As respostas estão na ordem em que foram recebidas e a escrita está mantida como cada um/a colocou no questionário.

Resposta recebida em 24 de agosto de 2016: “A mistura do clássico com elementos regionais" (OUVINTE 1, 2016) - mulher, pernambucana, residente em Pernambuco, não musicista. ${ }^{1}$ Respostas recebidas em 04 de outubro de 2016: "Desconheço a exatidão do termo, mas suponho ser a música instrumental desenvolvida em conjunto" (OUVINTE 2, 2016) mulher, 27 anos, pernambucana, residente em Pernambuco, não musicista. "Eu não sei o que é música armorial" (OUVINTE 3, 2016) - homem, 28 anos, alagoano, residente em Pernambuco, não músico. "É a música resultante do movimento de mesmo nome, idealizada por Ariano Suassuna, que buscava uma arte erudita nordestina, buscando o imaginário sertanejo" (OUVINTE 4, 2016) - homem, 23 anos, pernambucano, residente em Pernambuco, músico.

\begin{abstract}
Dentro dos contextos históricos do Movimento armorial, entendo que tal arte musical é tratada de forma híbrida, utilizando-se dos aspectos marcantes/característicos de práticas musicais tradicionais do nordeste brasileiro influenciados pela cultura ibérica (bandas de pife, cantorias de repente, caboclinhos, e outros), agregados aos padrões da música erudita europeia, em especial, a música medieval ibérica, detectando as aproximações estruturais musicais presentes nas duas expressões. Desta forma, iniciou-se uma sonoridade bastante peculiar a esta construção musical, gerando uma maneira diferenciada de compor música nordestina seguindo parâmetros europeus. (OUVINTE 5, 2016) mulher, 23 anos, pernambucana, residente em Pernambuco, musicista.
\end{abstract}

"Para mim, música armorial seria a música baseada nas raízes sertanejas nordestinas. Assume um caráter quase 'folclórico', no sentido de beber da fonte da cultura do povo" (OUVINTE 6, 2016) - homem, 26 anos, pernambucano, residente em Pernambuco, músico.

A música popular folclórica da região do nordeste do brasil, que por sua vez, se construiu por influência de outras culturas como: Árabe, Africana, Portuguesa, Holandesa..., A música Armorial é essa música de raiz trajada, organizada por instrumentos, formação e músicos eruditos; imitando a forma e sonoridade dos instrumentos rústicos. (OUVINTE 7, 2016) - homem, 35 anos, pernambucano, residente em Pernambuco, músico.

"Uma música construída com raízes tradicionais nordestina usando-se de elementos eruditos" (OUVINTE 8, 2016) - homem, 35 anos, pernambucano, residente em Pernambuco,

\footnotetext{
${ }^{1}$ Musicista nesse contexto é a mulher que faz música, tocando e/ou cantando. Não somente a pessoa que aprecia música. Por conta de um problema com meu computador, perdi 3 questionários. Os dos/as ouvintes 17,40 e 54 .
} 
músico. "Um movimento onde se pretendia enaltecer a música nordestina-pernambucana a partir de uma linguagem erudita" (OUVINTE 9, 2016) - homem, 36 anos, pernambucano, residente em Pernambuco, músico.

Respostas recebidas em 05 de outubro de 2016:

Vejo a música Armorial com uma perspectiva Eurocêntrica onde a música (cultura) erudita busca uma identidade regional se apropriando e delimitando uma "autenticidade"... há um purismo no movimento armorial tal como foi concebido que é bem típico do modernismo. (OUVINTE 10, 2016) - homem, residente em Pernambuco, músico. (Não respondeu nenhuma dessas perguntas. Mas eu tenho conhecimento disso).

"Um movimento artístico que visa destacar a música erudita com elementos da tradição nordestina" (OUVINTE 11, 2016) - mulher, 25 anos, pernambucana, residente em Pernambuco, musicista. "Movimento criado na década de 1970 que buscava criar uma música "erudita" e nordestina ao mesmo tempo. Personagens como Ariano Suassuna e o maestro Cussy de Almeida foram emblemáticas nessa construção" (OUVINTE 12, 2016) - homem, 44 anos, paulista, residente em Pernambuco, músico.

\begin{abstract}
Eu nunca tive até então muito envolvimento com trabalhos musicais no contexto armorial. Exceto, quando participei da Semana da Música da UFPE no ano de 2015, em que a instituição adotou o tema "Movimento Armorial 45 anos". Nessa eventualidade, eu, junto com alguns amigos formamos um grupo instrumental com repertório de música popular e incluímos duas músicas armoriais no repertório, as quais foram: "Mourão" do compositor Guerra Peixe e "Romance e Galope" do compositor Egildo Vieira. O pouco que sei sobre a música armorial, é que a mesma procura misturar raízes da música folclórica e popular do Nordeste com elementos ibéricos. Uma concepção que começou com o escritor Ariano Suassuna na literatura e depois se espalhou para outros movimentos artísticos como a música e a dança. Me parece uma tentativa de denotar, no contexto musical, uma característica mais erudita para a música popular nordestina. Para mim, o produto final soa muito interessante e consigo me identificar muito com uma música armorial quando a ouço. Ela me passa uma forte identidade nordestina. (OUVINTE 13, 2016) - homem, 23 anos, pernambucano, residente em Pernambuco, músico.
\end{abstract}

"Uma música que amarra as influências das expressões populares com a música erudita.

Criando um tipo de música singular ligada diretamente ao jeito, o cheiro e as texturas do Nordeste" (OUVINTE 14, 2016) - homem, 32 anos, pernambucano, residente em Pernambuco, músico.

Música Armorial. Lembra algo ligado a Ariano Suassuna. Contudo, sinceramente não sabia da ligação da música clássica a popular. Vim saber na verdade, por curiosidade no google. Pouco investido e divulgado, infelizmente. Embora seja a raiz da nossa cultura nordestina. Quis dizer: pouco investimento. (OUVINTE 15, 2016) - mulher, 40 anos, pernambucana, residente em Pernambuco. Não respondeu se é musicista ou não. Sobre isto escreveu o seguinte: "Não sou da área, mas curto" (OUVINTE 15, 2016). 
"Música armorial é um movimento que preza pela cultura de raízes, algo tipicamente Nordestino como: os romances em poesias, literatura de cordel, música de viola, pífano, junto a arte de xilogravura que faz toda a ilustração da obra" (OUVINTE 16, 2016) - homem, 30 anos, pernambucano, residente em Pernambuco, não músico.

Respostas recebidas em 06 de outubro de 2016: "Uma música de cunho erudito, apresentando característica nordestina, ora feita com instrumentos tradicionais do nordeste ora feita com orquestra de cordas, de câmara ou sinfônica" (OUVINTE 18, 2016) - homem, 21 anos, pernambucano, residente em Pernambuco, músico. "Eu não sei muita coisa sobre esse tipo de música. Só que é erudita com características do nordeste” (OUVINTE 19, 2016) mulher, residente em Pernambuco, musicista. (Não respondeu nenhuma dessas perguntas. Mas eu tenho conhecimento disso). "No meu entendimento, é uma mistura de música européia (sic) do período renascentista, no que tange à parte teórica musical, com os cânticos entoados por populares que foram transmitidos oralmente desde a era da colonização portuguesa aqui no Nordeste" (OUVINTE 20, 2016) - homem, 49 anos, pernambucano, residente em Pernambuco, músico.

\begin{abstract}
Não sei o conceito. Mas tenho o sentimento que é algo que fala da nossa origem pernambucana. Nosso povo, nossa vida, nosso amor e apego pela terra. Nossa terra. Ela tem nossa cara, expressa nosso sentimento coletivo, elevando e propagando nossa cultura. (OUVINTE 21, 2016) - mulher, 67 anos, pernambucana, residente em Pernambuco, não musicista.
\end{abstract}

Respostas recebidas em 08 de outubro de 2016: “A música Armorial, foi um movimento artístico inspirado no sertanejo. Tendo como fundador o escritor Ariano Suassuna, um movimento que inclui todas as artes, não só a música” (OUVINTE 22, 2016) - homem, 35 anos, pernambucano, residente em Pernambuco, músico. "Como sou do nordeste e conheço a história fica mais fácil responder. Surgiu com a intenção de valorizar os preceitos da música do nordeste com o erudito, essa era a intenção de Ariano Suassuna" (OUVINTE 23, 2016) mulher, 48 anos, pernambucana, residente em Pernambuco, musicista.

Respostas recebidas em 09 de outubro de 2016:

É uma música que surgiu no Movimento Armorial, liderado por Ariano Suassuna. Tem uma proposta de quebrar as barreiras entre as músicas ditas popular e erudita, criando uma linguagem que expressa o popular/folclórico/cultura regional de maneira mais rebuscada. (OUVINTE 24, 2016) - mulher, 24 anos, pernambucana, residente em Pernambuco, musicista. 
"Música ligada ao movimento Armorial, pensado por Ariano Suassuna, transformando a música erudita nordestina, fazendo música com instrumentos regionais" (OUVINTE 25, 2016) - mulher, 26 anos, pernambucana, residente na Paraíba, musicista.

Respostas recebidas em 12 de outubro de 2016: "Música armorial é a música que une o estilo nordestino com o erudito. Músicas inspiradas em instrumentos regionais como rabeca, viola e pífano, além das cantorias, que busca elementos de suas raízes ibéricas" (OUVINTE 26, 2016) - mulher, 27 anos, pernambucana, residente na Paraíba, musicista. "É a música que tem em seus elementos constituintes, como harmonia, ritmo e melodia, o eco dos traços e costumes de um dado povo" (OUVINTE 27, 2016) - mulher, 35 anos, paraibana, residente na Bahia, não musicista. (Embora tenha respondido que não é musicista, tenho conhecimento de que ela toca um instrumento, pelo menos).

Não conheço muito sobre música armorial. Num raso conhecimento sei que o Movimento Armorial foi um movimento encabeçado pelo mestre Ariano Suassuna e que buscava agregar os elementos típicos nordestinos na arte dita erudita. No caso da música, trazer, por exemplo, o uso dos modos musicais comumente utilizados na música popular nordestina, os instrumentos (como a rabeca), a temática e etc. (OUVINTE 28, 2016) - homem, 21 anos, pernambucano, residente em Pernambuco, músico.

Respostas recebidas em 24 de outubro de 2016:

Um tipo de música que tentou perpetuar uma ideia de música erudita brasileira genuína usando elementos da música de tradição oral do nordeste especificamente, além de músicas de origem europeia como as músicas da península ibérica misturada com a música erudita. Uma espécie de versão nordestina dos movimentos nacionalistas dentro da música. (OUVINTE 29, 2016) - homem, 24 anos, paulista, residente em Pernambuco, músico.

O Movimento Armorial surgiu na década de 70 em Pernambuco com o objetivo de representar as expressões populares nordestinas com relação a música de viola, rabeca e pífano e através da literatura de cordel e suas xilogravuras. Seu principal mentor foi Ariano Suassuna, que incentivou o início desse movimento com enfoque na pintura, música, literatura, cerâmica, dança, escultura, tapeçaria, arquitetura, teatro, gravura e cinema. (OUVINTE 30, 2016) - homem. (Não respondeu nenhuma dessas perguntas pessoais).

"Música Armorial é um estilo musical formado a partir do Movimento Armorial, que busca valorizar os elementos da cultura popular brasileira e mostrar quão rica e distinta é a música comercialmente pop mundial" (OUVINTE 31, 2016) - homem, 26 anos, pernambucano, residente em Pernambuco, músico. "É a experiência de se fazer uma música erudita nordestina utilizando como fonte inspiracional as cantorias da região e seus acompanhamentos típicos, como a rabeca, a viola sertaneja e a banda de pífanos" (OUVINTE 32, 2016) - homem, 37 anos, pernambucano, residente em Pernambuco, não músico. "Penso 
que a musical armorial seja o resultado de um estilo que abarca características e traços da cultura nordestina. Imagino que parte das composições musicais deste estilo surgem como reflexo e influência de uma vivência no nordeste brasileiro" (OUVINTE 33, 2016) - homem, 30 anos, pernambucano, residente em Minas Gerais, músico.

\begin{abstract}
O que eu já li sobre o assunto é que é uma música popular que tenta ser convertida em música erudita, principalmente aqui no Nordeste. Se não me engano tem alguma relação com Ariano Suassuna. É uma tentativa de transformar música popular, ou arte popular, em algo erudito. (OUVINTE 34, 2016) - homem (não respondeu esse item), 42 anos, pernambucano, residente em Pernambuco. Não respondeu se é músico ou não.
\end{abstract}

"Música erudita que traz consigo elementos das raízes populares da nossa cultura" (OUVINTE 35, 2016) - mulher, 28 anos, pernambucana, residente em Pernambuco, musicista. "Que eu saiba, o Movimento Armorial tinha como objetivo a criação de um tipo de arte erudita local. A música Armorial, pra mim, é a música produzida pelos artistas que participaram deste movimento" (OUVINTE 36, 2016) - homem, 36 anos, pernambucano, residente em Pernambuco, músico.

Respostas recebidas em 30 de outubro de 2016: "Eu penso que seja o gênero musical relacionado ao Movimento Armorial. Gênero que contém elementos essencialmente nordestinos, sem influência clara de cultura adversas" (OUVINTE 37, 2016) - homem, 25 anos, pernambucano, residente em Pernambuco, músico.

É a música que retrata o nosso sertão. Tem estrutura modal ou polimodal, podendo se concentrar no modo jônio ou eólio. Porém, os modos mais característicos são dórico e lídio-mixolídio. Vejo a música armorial como uma música de concerto instaurada sobre os elementos do folclore e da cultura popular do nordeste, principalmente o sertão pernambucano, já que seu principal mentor, Ariano Suassuna, foi um paraibano erradicado no Recife. (OUVINTE 38, 2016) - homem, 32 anos, pernambucano, residente em Pernambuco, músico.

"Não tenho conhecimento. Já ouvi vagamente o termo" (OUVINTE 39, 2016) - mulher, 51 anos, pernambucana, residente em Pernambuco, não musicista.

É um estilo musical que emergiu a partir dos anos 70 e buscou sofisticar a música nordestina dando-lhe um perfil erudito. Seu padrinho foi o escritor Ariano Suassuna que se inspirava em elementos da cultura popular como a literatura de cordel, os mamulengos, a xilogravura, como também o pífano, a viola e a rabeca, para produzir uma musicalidade genuinamente regional e brasileira. (OUVINTE 41, 2016) - homem, residente em Pernambuco. (Não respondeu nenhuma dessas perguntas. Mas eu tenho conhecimento das informações que aqui coloquei).

Pouco ouvi falar sobre música armorial enquanto estive na Universidade, ou talvez não dei a devida importância quando alguém falou desse movimento para mim. Não conseguiria falar muito bem no assunto porque não tenho tanto conhecimento, porém, pelo que já ouvi é relacionado à cultura nordestina, os instrumentos mais 
apropriados para acompanhar os cordéis e as danças. (OUVINTE 42, 2016) mulher, 28 anos, pernambucana, residente em Pernambuco, musicista.

Para mim, música armorial é todo o repertório que me remeta à música nordestina, não ritmos locais como frevo, maracatu, forró, mas um tipo de música em que me reporte à vida e ao homem sertanejos. Eu percebo isso pela instrumentação (percussão, cordas friccionadas, flauta transversa, acordeon), pelo padrão rítmico bastante marcante, pela presença do sistema modal (em geral os modos mixolídio, lídio e a escala nordestina que é uma fusão entre estes). Além do fato de lembrar a nossa música, também me remete à música profana medieval (baixa Idade Média) como danças e canções desta época. (OUVINTE 43, 2016) - homem, 22 anos, pernambucano, residente em Pernambuco, músico.

A música Armorial é aquela que leva em sua composição elementos pertencentes à cultura popular nordestina, trazendo em si instrumentos musicais típicos da região juntamente com os mais utilizados em grupos de câmera, além de possuir elementos da música modal com influências do barroco, mas com ritmos nordestinos. (OUVINTE 44, 2016) - homem (não respondeu a essa pergunta, nem disse a idade), pernambucano, residente em Pernambuco, músico (não respondeu a essa última também, mas sei que é músico).

"Um estilo musical com influências eruditas e da cultura nordestinas" (OUVINTE 45, 2016) - homem, 36 anos, pernambucano, residente em Pernambuco, músico. "Música Armorial é música erudita com elementos da música popular nordestina” (OUVINTE 46, 2016) - mulher, 31 anos, pernambucana, residente em Pernambuco, musicista. "É uma música que busca valorizar as raízes culturais nordestinas e que busca inspiração nas canções da região, na sonoridade dos instrumentos típicos e também na vida do sertanejo/nordestino. Uma música dita "erudita", mas com raízes populares" (OUVINTE 47, 2016) - mulher, 24 anos, pernambucana, residindo no Rio Grande do Sul, musicista.

É uma música de concerto baseada na pesquisa e recriação de formas de expressão do folclore musical brasileiro, dialogando também com a música antiga europeia - entenda-se: medieval, renascentista, barroca e pré-clássica, nos resquícios que se apresentam na cultura tradicional brasileira e também em elementos vindos da pesquisa. Também é ligada às ideias do modernismo nacionalista de Mário de Andrade e Villa-Lobos, na busca pela autenticidade para a música de concerto brasileira, através do diálogo com o folclore musical. Uma sonoridade singular dentro da música de concerto brasileira, que nos anos de 1970 vivia uma influência grande das vanguardas europeias e sua complexidade. Nesse panorama, o armorial tem como proposta uma busca pela expressão singela e direta. (OUVINTE 48, 2016) - homem, 27 anos, pernambucano, residindo em Pernambuco, músico.

"Acho que a junção da música erudita com a música popular do nordeste Brasileiro" (OUVINTE 49, 2016) - mulher, 26 anos, pernambucana, residindo em Pernambuco, musicista. "Não sei responder de forma direta o que seria música armorial, já que não tenho contato ou se tenho realmente não o percebo" (OUVINTE 50, 2016) - homem, 21 anos, paulista, residindo em Pernambuco, músico. 


\begin{abstract}
A priori um projeto objetivado em uma sonoridade popular/raiz/folclórica com um embasamento/aprofundamento do erudito ou melhor dizendo um aprofundamento do conceitual erudito em uma musicalidade folclórica em seu sentido + amplo! (OUVINTE 51, 2016) - homem, 55 anos, pernambucano, residindo em Pernambuco, não músico.
\end{abstract}

"Para mim, a música Armorial é a nossa valorização musical como nordestinos, que se deu no Movimento Armorial a fim de valorização não só da música mas como da arte da dança, das artes plásticas, tudo teve um sentido nessa época" (OUVINTE 52, 2016) - mulher, 26 anos, paraibana, residindo na Paraíba, musicista. "É a música resultante da fusão da tradição musical europeia com os elementos da música nordestina, atribuindo uma certa erudição à imagem da música popular tradicional" (OUVINTE 53, 2016) - mulher, 23 anos, pernambucana, residindo em Pernambuco, musicista. "Música de origem nordestina, composta, tocada ao estilo e maneira da música Barroca, especialmente, a que lembra J. S. Bach. Ou seja, ter uma forma e utilizar instrumentos musicais de concerto" (OUVINTE 55, 2016) - homem, 56 anos, paraibano, residindo na Paraíba, músico. "Música que busca retratar determinado povo ou região" (OUVINTE 56, 2016) - homem, 31 anos, pernambucano, residindo em Pernambuco, músico. "Comecei a estudar música agora, mas não na faculdade ainda. Não entendo nada, nem ainda tinha ouvido falar em Música Armorial" (OUVINTE 57, 2016) - mulher, 35 anos, pernambucana, residindo na Paraíba, não musicista.

"É toda música produzida pelos compositores que fizeram e fazem parte do Movimento Armorial criado por Ariano Suassuna em 1970" (OUVINTE 58, 2016) - homem, 24 anos, pernambucano, residindo em Pernambuco, músico. "É a música desenvolvida no período citado no texto acima [breve explanação que havia no documento enviado], que buscava criar uma música nos moldes erudito, embora com raízes fincadas na música/cultura popular nordestina brasileira" (OUVINTE 59, 2016) - mulher, 22 anos, pernambucana, residindo em Pernambuco, musicista. "Confesso não conhecer muito acerca dela. Mas pelo que conheço, é uma música maravilhosa e muito representativa para o cenário cultural do nosso estado e mesmo tendo influência no país" (OUVINTE 60, 2016) - homem, 27 anos, pernambucano, residindo em Pernambuco, não músico.

Respostas recebidas em 31 de outubro de 2016: "É a criação de uma arte erudita valorizando as raízes culturais brasileiras" (OUVINTE 61, 2016) - homem, 30 anos, pernambucano, residindo em Pernambuco, músico. "Para mim é a música a partir do Movimento Armorial" (OUVINTE 62, 2016) - homem, 43 anos, paraibano, residindo em 
Pernambuco, músico. "Pelo pouco conhecimento que tenho sobre o assunto, a meu ver a música armorial seria um estilo voltado à cultura musical erudita do nordeste do Brasil" (OUVINTE 63, 2016) - homem, 24 anos, pernambucano, residindo em Pernambuco, músico.

Respostas recebidas em 04 de novembro de 2016:

É uma música de estrutura erudita com "sotaque" nordestino. Música de estrutura erudita, mas que ressalta elementos musicais da música popular nordestina. Música erudita com sonoridade de nordeste. Percebo ainda uma influência maior do estado de Pernambuco. (OUVINTE 64, 2016) - mulher, 33 anos, pernambucana, residindo em Pernambuco, musicista.

"É a fusão da música regional pernambucana com a música erudita" (OUVINTE 65, 2016) - homem, 24 anos, pernambucano, residindo em Pernambuco, músico.

\begin{abstract}
Depende muito. Se a música armorial é concebida, apenas, como um movimento voltado à cultura nordestina sertaniense, pouco se nota a influência. Entretanto, se concebida como cultura geral da nação, tenho dois pontos de vista: 1. Diretamente. Neste caso, não. Devido à intenção de quem produz música. Maioria de nossa produção musical (generalizar, não poderia) não desenvolvem trabalhos musicais com a intenção de fazer música com o teor armorial ou com influência armorial. 2. Indiretamente. Neste caso, sim. Falo de trabalhos musicais onde, inconscientemente, se fazem presentes elementos armoriais. Ou seja, mesmo sem a intenção dos compositores. Músicas como o Axé, Sertanejo Universitário, Samba, Pagode... levam traços da cultura popular. (OUVINTE 66, 2016) homem, 30 anos, pernambucano, residindo em Pernambuco, músico.

A priori, eu poderia dizer que a "música armorial" é toda aquela que, em sua concepção e composição, busca se alinhar com os preceitos estéticos do Movimento Armorial. Por outro lado, todo movimento estético transita num espaço cronológico e, para continuar influenciando a produção artística, em muitos casos, tal movimento precisa ajustar-se ao mundo em que se insere. Não se trata de uma mudança na essência, mas nas formas de se discursar sobre essa essência. Creio que o que acontece com a Música Armorial é mais ou menos isso: buscar manter a essência estética por meio de novas formas de discurso. (OUVINTE 67, 2016) - homem, 30 anos, pernambucano, residindo em Pernambuco, músico.
\end{abstract}

"Movimento artístico-cultural, com finalidade de promover a arte e cultura do nordeste" (OUVINTE 68, 2016) - homem, 46 anos, pernambucano, residindo em Pernambuco, músico. “É um movimento musical que faz música erudita utilizando a cultura do Nordeste e seus ritmos ou vice-versa. É a mistura de técnicas com jeito de tocar, instrumentos eruditos com regional e o popular com clássico" (OUVINTE 69, 2016) - homem, 31 anos, pernambucano, residindo em Pernambuco, músico. "É a tentativa e a busca pela criação da arte erudita, preservado as raízes culturais nacionais" (OUVINTE 70, 2016) - homem, 20 anos, paulista, residindo em Pernambuco, músico. 
É uma corrente artística com características distintas e familiares do nordeste e que acredito tem a ver com literatura de cordel e cultura popular. É um tipo de música que eles misturam banda de pífano e outros instrumentos. Tive conhecimento da música armorial através da influência de Ariano Suassuna, mas não sei muita coisa. (OUVINTE 71, 2016) - mulher, 30 anos, pernambucana, residindo em Pernambuco, não musicista.

\section{"Para mim seria um tipo de música erudita mas com traços da cultura nordestina"}

(OUVINTE 72, 2016) - mulher, 31, pernambucana, residindo em Pernambuco, musicista.

Música Armorial é a tentativa de consolidar características próprias mesmo recebendo influências de outras culturas. Ela consegue transformar a imagem da música nordestina que seria de lamento/festeira, por exemplo, em outra com fibra, marcante, e mesmo assim, sem perder a essência do homem que sofre com a seca e que acorda todos os dias para lutar novamente. (OUVINTE 73, 2016)-homem, 36 anos, pernambucano, residindo em Pernambuco, músico.

"Música Armorial, para mim, é uma linguagem musical que apresenta ritmo, melodia e harmonia que lembram uma vida campestre, rústica, com traços de melancolia, alegria e fantasia" (OUVINTE 74, 2016) - homem, 35 anos, paulista, residindo em Pernambuco, músico.

Não conheço exatamente o conceito, mas acho que a música Armorial tem haver (sic) com as músicas populares Pernambucana, Acho que, Maestro Spok é um exemplo, pois o mesmo utiliza instrumentos de músicas clássicas para tocar musicam populares. Como sou da dança, (Graduanda em dança) entendo o Movimento Armorial como uma mistura do popular e erudito que se permeou na Cultura Pernambucana. (OUVINTE 75, 2016) - mulher, 23 anos, pernambucana, residindo em Pernambuco, não musicista.

Acredito que a Música Armorial se configura enquanto um processo mutuo entre os vários elementos da música e da cultura popular nordestina, regidos e/ou organizados, a partir dos conceitos e fundamentos da tradição musical europeia (ou música "erudita"). A partir de uma visão pessoal, acredito que o objetivo principal do Movimento Armorial, em suas diversas áreas, era de criar uma arte popular nordestina "pura", livre de imposições e influência culturais estrangeiras e que, ao mesmo tempo, retratasse o idiomatismo sonoro, artístico e cultural da região nordeste, a partir de um viés erudito (rebuscado, refinado). Entretanto, essa busca por uma arte nordestina erudita, a meu ver, acabou dando a música e ao Movimento Armorial um caráter elitista o que, de certo modo, não condiz com o cenário sociocultural, bem como os sujeitos (cantadores, músicos, dançarinos, cordelistas e etc) que representam toda a gama de artistas da cultura popular. Apesar dessa visão em torno dos aspectos ideológicos arraigados ao Movimento Armorial, acredito que a música e as expressões desse movimento têm valor musical e cultural enorme para a cultura nordestina e brasileira. (OUVINTE 76, 2016) - homem, 28 anos, pernambucano, residindo em Pernambuco, músico.

Apesar de ser de Pernambuco, nunca ouvi falar de Música Armorial, mas após essa participação, resolvi pesquisar sobre o assunto e me deparei com nomes como Guerra-Peixe, Capiba, Clóvis Pereira, Antônio Madureira, Antonio Nóbrega, os quais ouvi falar e já toquei músicas deles, só não sabia sobre o movimento chamado Armorial, que nada mais é do que música erudita com elementos culturais do nordeste. (OUVINTE 77, 2016) - homem, 27 anos, pernambucano, residindo no Mato Grosso do Sul, músico.

É um estilo de Música Popular, bem trabalhada, com elementos típicos da cultura nordestina, com uma roupagem que denota e exalta o ritmo nordestino, bem como, os instrumentos musicais presentes em outros estilos nordestinos, como triângulo, 
rabeca, dentre outros. (OUVINTE 78, 2016) - homem, 30 anos, pernambucano, residindo no Rio Grande do Norte, músico.

Respostas recebidas em 09 de novembro de 2016:

É uma arte que tem como objetivo valorizar a cultura popular nordestina usando elementos como: literatura de cordel, rabeca (esse para acompanhar os que recitam os versos) e misturando ao erudito. Mas acredito que a ideia era, na verdade, criar uma arte erudita brasileira. (OUVINTE 79, 2016) - está sem nome e demais informações. Marcou a opção de músico/a.

"É a tentativa de construir uma música erudita a partir de elementos da música tradicional do nordeste brasileiro" (OUVINTE 80, 2016) - homem, 32 anos, pernambucano, residindo em Pernambuco, músico.

Movimento que tentou conciliar a cultura nordestina, mais precisamente as de caráter mouro, ao instrumental e espaço erudito. Explorou tanto sonoridades, com as escalas "nordestinas" (dórica e mixolídia), como as formas de expressão poética e cênica da cultura trovadoresca medieval. (OUVINTE 81, 2016) - homem, 34 anos, pernambucano, residindo em Pernambuco, músico.

"A música criada no período do famoso Movimento Armorial, que tem raízes na cultura folclórica Pernambucana" (OUVINTE 82, 2016) - homem, 54 anos, pernambucano, residindo em Pernambuco, músico.

Um movimento no nordeste criado nos anos 70, pelo escritor Ariano Suassuna numa tentativa de fazer música erudita nordestina usando como inspiração as cantorias da região e seus acompanhamentos típicos, como a rabeca, a viola sertaneja e a banda de pífanos. (OUVINTE 83, 2016) - mulher, 26, pernambucana, residindo em Pernambuco, musicista.

“É uma música aparentemente erudita, porém, executada com inspiração no folclore popular, ou seja, é um maracatu, cavalo marinho, forró, com um revestimento clássico" (OUVINTE 84, 2016) - homem, 22 anos, pernambucano, residindo em Pernambuco, músico.

A música Armorial é aquela que tem como traço comum principal o romance popular do Nordeste como a Literatura de Cordel e utiliza também como comunicação e interação a xilogravura como comunicação e que também tem por característica o acompanhamento de alguns instrumentos como o pífano, a rabeca, a viola. (OUVINTE 85, 2016) - homem, 37 anos, pernambucano, residindo em Pernambuco, músico.

“A música armorial faz parte de um movimento que procura resgatar a cultura Nordestina em sua essência" (OUVINTE 86, 2016) - homem, 29 anos, pernambucano, residindo em Pernambuco, músico. "Para mim, Música Armorial é um gênero que busca executar modalidades de música nordestina com uma roupagem europeia, erudita" (OUVINTE 87, 2016) - homem, 28 anos, pernambucano, residindo em Pernambuco, músico. 
Respostas recebidas em 10 de novembro de 2016: "Música que sofre influência interiorana, de uma cultura um tanto rústica e artesanal. Reflete um estado de expressão cotidiana de uma vivência simples mas forte em um meio nada favorável ao desenvolvimento" (OUVINTE 88, 2016) - homem, 22 anos, pernambucano, residindo em Pernambuco, não músico.

"É uma música que valoriza a cultura de tradição oral, (cultura popular) com uma linguagem mais elabora "mais erudita". Através de, melodias, contraponto, harmonias, ritmos que lembram a música nordestina" (OUVINTE 89, 2016) - homem, 33 anos, pernambucano, residindo em Pernambuco, músico. "Cultura popular nordestina aliando, música com cordel, pífano e rabeca" (OUVINTE 90, 2016) - homem, 31 anos, pernambucano, residindo em Pernambuco, músico. "Música característica do Movimento Armorial que tem sua base na construção erudita acrescida de elementos típicos da cultura popular" (Resposta que encontrei nos meus arquivos. Provavelmente de alguns dos/as três ouvintes que perdi).

\section{Onde estão as influências armoriais? (respostas das/os ouvintes)}

Alguns/mas ouvintes não responderam a essa pergunta.

Resposta recebida em 24 de agosto de 2016: "Na música de artistas como Antonio Nóbrega, nas festas populares como o Carnaval, nos blocos de rua" (OUVINTE 1, 2016) mulher, pernambucana, residente em Pernambuco, não musicista.

Respostas recebidas em 04 de outubro de 2016: “O que percebo é que o termo Música Armorial está relacionado a eventos culturais, um pouco distante das músicas e ritmos da "moda". Posso supor que esteja relacionada a ritmos populares como frevo, porém não estou certa" (OUVINTE 2, 2016) - mulher, 27 anos, pernambucana, residente em Pernambuco, não musicista. "E também não percebo influência desse tipo de música" (OUVINTE 3, 2016) homem, 28 anos, alagoano, residente em Pernambuco, não músico.

O que percebo é que esta música parece ter imprimido a "cara" nordestina, sertaneja de tal forma que a escutamos, tanto a música quanto alguns padrões estéticos em novelas, filmes que busque aquele imaginário. No mais só escuto em recitais voltado ao Armorial ou em grupos que buscam a mesma estética. (OUVINTE 4, 2016) - homem, 23 anos, pernambucano, residente em Pernambuco, músico.

Consigo perceber tais influências dessa música em vários segmentos da cena musical da atualidade de Recife-PE e em João Pessoa-PB (e em várias localidades brasileiras). De modo que tal expressão, no momento de sua formação, foi grandemente expandida por todo país. Neste período de Ascenção, do M.A., as 
produções dos artistas envolvidos, acabaram influenciando sua geração e as gerações seguintes, dando continuidade a esta tendência. Em Recife, berço do Movimento, as instituições musicais têm uma grande importância neste processo de "continuidade" desta vertente de produções artísticas, onde estes músicos envolvidos vieram a torna-se professores e a formar novos grupos com esta linguagem composicional. O CPM e a UFPE são instituições que possuem vários grupos representativos ligados a estas influências em Pernambuco, além das orquestras sinfônicas, destacando a Orquestra Sinfônica do Recife. Muitos compositores e grupos de música instrumental, abordam de certa forma esta vertente em seus repertórios, incluindo peças dos compositores que participaram ativamente do movimento (como Antônio Madureira, Cussy de Almeida, GuerraPeixe), utilizando da ideia primordial do hibridismo musical. Acredito que as influências perceptíveis da M.A. na atualidade, utiliza-se de um sentido metafórico, de pertencimento e de caracterização da identidade de uma música erudita nordestina, onde os grandes nomes deste movimento, foram os responsáveis por um "modelo" sonoro, fazendo uma ótima leitura musical da ideia de criação uma arte erudita com base nos elementos da tradicional do nordeste brasileiro proposta por Ariano Suassuna. (OUVINTE 5, 2016) - mulher, 23 anos, pernambucana, residente em Pernambuco, musicista.

Consigo, mas de forma bastante esparçada. (sic) nas regiões nordestinas é uma música que tem sido usada como influência em bandas locais, mas de forma muito suave, sem um aprofundamento que evidencie tal influência no resultado sonoro de forma significativa. (OUVINTE 6, 2016) - homem, 26 anos, pernambucano, residente em Pernambuco, músico.

$\mathrm{Na}$ atual música de concerto, segue a ideia de desconstrução: recorte de elementos tipos do estilo Armorial, mas usados apenas de forma esporádica para fazer rápida menção e que mesmo assim, antes de uma explicação acadêmica ou visual, muitas vezes passam despercebido.... Essa desconstrução existe tanto na escrita como na excussão e são muitas vezes uma verdadeira tortura para o instrumentista quanto para o ouvinte, ou seja, é uma música para ouvido analítico, uma experiência acadêmica (intelectual ou não), não há sentimento, é frio e puramente matemático, não é uma música para concerto...difícil até chamar de arte. Se ela já não atinge os ouvidos de apreciação do público erudito, é uma verdadeira agressão aos ouvidos do público de raiz, de onde se originou. Mas essa tem sido uma tendência mundial na arte em geral, que provavelmente será esquecida em sua maior porcentagem em tempos vindouros, pois já existem movimentos em alguns países retomando o tonalismo, se não em sua totalidade, mas com o propósito de fazer música se ouvir, para apreciar, deixando o processo de composição em último plano. Hoje, felizmente ainda existem alguns pequenos artistas e grupos que resistem fazendo esse tipo de música de forma tradicional... a maioria violão instrumental ou voz e violão, há também uma mistura com outros gêneros como choro e jazz e forró e frevo, (a Rabeca tem ganho (sic) espaço nessas formações) mas todos esses permanecem praticamente invisíveis para a maioria dos considerados "produtores de música de concerto". Esses grupos sobrevivem de pequenos projetos culturais ou quando ganham reconhecimento fora do país, sendo visto pelos nossos apenas quando há um propósito de pesquisa acadêmica. (OUVINTE 7, 2016) - homem, 35 anos, pernambucano, residente em Pernambuco, músico.

Em vários artistas locais, como os citados na apresentação da pesquisa, em trilhas sonoras de filmes e material publicitário. Geralmente aparece com mais força nas festas tradicionais como São João e carnaval. Muito usado também no teatro e nas apresentações folclóricas de escolas em geral. (OUVINTE 8, 2016) - homem, 35 anos, pernambucano, residente em Pernambuco, músico.

Percebo essa influência em dois grupos: o SaGRAMA e o Retratos do Nordeste. Vejo que as músicas são de caris nordestinos, as vezes (sic) são utilizados 
instrumentos típicos e sobretudo, apesar de ser música popular, a maneira com que são produzidos os arranjos e executados me remete a idéia (sic) erudita. (OUVINTE 9, 2016) - homem, 36 anos, pernambucano, residente em Pernambuco, músico.

Respostas recebidas em 05 de outubro de 2016:

Vejo a influência sendo limitada a poucos grupos como SaGRAMA... Isso se dá ao fato desse purismo que se utiliza de formas eruditas com Modos Mixolidio; Lidio; Dorico; Ritmos do Nordeste que geralmente excluem a afro-descendência... gerar uma inevitável estagnação composicional. Gosto da música armorial, mas ela teve seu momento histórico na reafirmação de algumas identidades. Todo movimento deve ser transcendido... Isso é vital para a criatividade. (OUVINTE 10, 2016) - homem, residente em Pernambuco, músico. (Não respondeu nenhuma dessas perguntas. Mas eu tenho conhecimento disso).

"Saindo do âmbito da Universidade Federal, não consigo perceber muito a Música Armorial. Como se este movimento artístico estivesse restrito ao ambiente intelectual" (OUVINTE 11, 2016) - mulher, 25 anos, pernambucana, residente em Pernambuco, musicista.

A Música em Pernambuco recebe influências dos mais variados estilos. O Movimento Armorial não poderia ficar de fora. Hoje percebemos a presença de instrumentos e repertório "erudito" cada vez mais presentes na Música Popular. O Movimento Armorial contribuiu muito pra isso. (OUVINTE 12, 2016) - homem, 44 anos, paulista, residente em Pernambuco, músico.

Conheço poucos grupos que trabalham com música armorial. Creio que isso ocorra porque não tenho muita familiaridade com o assunto. Esses grupos que conheço estão todos localizados no Recife e são de formação instrumental. São eles: SaGRAMA, oQuadro e Orquestra de Câmara do CPM. Sinceramente eu não consigo ver a música armorial impactando muito na atualidade, pois para mim ela parece ainda está muito restrita à (sic) ambientes acadêmicos e salas de concertos. Fatores estes que não se aproximam muito do público geral. Acredito também que falta muito esclarecimento sobre o tema para a população, inclusive para os músicos. Dos músicos que tenho proximidade, a maioria ou tem um conhecimento muito superficial sobre o assunto, ou não tem conhecimento. Acredito que uma maneira de difundir mais o Movimento Armorial, seria com os professores de música abordando o tema em escolas de música com mais frequência, pois eu mesmo na minha formação, só ouvi falar do Movimento Armorial quando cheguei na Universidade. Outra medida seria a criação de mais grupos que trabalhem com esse repertório e que se apresentassem em localidades mais populares, além das localidades já citadas. (OUVINTE 13, 2016) - homem, 23 anos, pernambucano, residente em Pernambuco, músico.

"SaGRAMA e Antônio Carlos Nóbrega seriam as primeiras referências que vêm à lembrança. A primeira mais ligada a música erudita, e Nóbrega, mais ligado à música popular"

(OUVINTE 14, 2016) - homem, 32 anos, pernambucano, residente em Pernambuco, músico.

A cultura popular está em toda parte no entanto, ainda há uma dicotomia com a música clássica. E o velho paradigma de que "popular" "não combina ao clássico". Todavia a raiz desta, vem todo o legado cultural ao musical de uma forma geral. Ex: Conheci a rabeca, através de uma colega de classe, chamada Aglaia, Senão, jamais, embora nordestina. O abismo maior é a valorização e principalmente, 
investimento numa cultura tão rica, contudo "ignorada". (OUVINTE 15, 2016) mulher, 40 anos, pernambucana, residente em Pernambuco.

A cultura de um povo não morre, é algo que se estende e resiste ao tempo; principalmente em nossa região Nordeste isso permanece bem firme como uma tatuagem firmada à pele. Vejo em várias partes como quadros em museus ilustrando algumas figuras em xilogravura e também obras de Literatura de Cordel, fora desses espaços culturais vejo no São João de nossa região principalmente em Caruaru em forma de música de viola com cantores regionais muitos são acompanhados por tocadores de pífanos, um que conheço é João do Pife de Caruaru. (OUVINTE 16, 2016) - homem, 30 anos, pernambucano, residente em Pernambuco, não músico.

Respostas recebidas em 06 de outubro de 2016: "Sim, na produção musical e na estética abordada por alguns compositores - Egildo Vieira, Nelson Almeida e Dierson Torres - eles apresentam ou apresentaram diversas composições dentro da estética armorial" (OUVINTE 18, 2016) - homem, 21 anos, pernambucano, residente em Pernambuco, músico. "Não consigo percebê-la na atualidade, mas queria conhecer." (OUVINTE 19, 2016) - mulher, residente em Pernambuco, musicista. "O grupo que a utiliza com mais propriedade é sem dúvida o SaGRAMA, que eu considero como um herdeiro musical. Antonio Nóbrega e Antúlio Madureira também fazem uso desse movimento artístico cultural" (OUVINTE 20, 2016) homem, 49 anos, pernambucano, residente em Pernambuco, músico.

Sim. Dentro do nosso Estado. Nosso mundo musical. Pouca projeção nacional ou mundial. Mas muito forte e pura. Coisa de raiz. De que maneira? Faz parte do pernambucano enaltecer nossas qualidades. Somos melhor em tudo. Temos o maior carnaval do mundo, temos o São João melhor do mundo. Nossas praias são as mais lindas do mundo. Temos os homens mais machos do mundo. Mesmo assim somos Amélia. Com tudo isso, reconhecemos o respeito e admiração dos grandes músicos nacionais e internacionais por nossa música. Muitos compositores e músicos pernambucanos que são reconhecidos e estimados pelo mundo a fora (sic), e as vezes (sic) desconhecidos aqui. Ou não valorizados e prestigiados como lá fora, principalmente no exterior. Como Naná Vasconcelos e Moacir Santos (conheci sua história e projeção recentemente). Assim deve ter muitos. Apesar do nosso grande orgulho por nossa cultura, ignoramos o brilho e a projeção daqueles que levam a nossa história e os nossos valores, tão longe. Revendo o texto, com relação a influência do Movimento Armorial e música armorial, no atual cenário musical em Pernambuco, considero um desenvolvimento isolado, de um grupo de músicos locais, com uma sensibilidade e capacidade diferenciada, que não se propaga para massa que hoje desponta, e faz o que é hoje a música pernambucana. Esta aproxima-se mais da prática e gosto da cultura popular, do gosto popular pelo frevo, forró, maracatu e "mangue bit". Contaminados também pelo funk. (OUVINTE 21, 2016) - mulher, 67 anos, pernambucana, residente em Pernambuco, não musicista.

Resposta recebida em 08 de outubro de 2016: "Sim. Através dos grupos musicais regionais que ainda predomina o cenário musical do Recife e também nos grupos teatrais" (OUVINTE 23, 2016) - mulher, 48 anos, pernambucana, residente em Pernambuco, musicista. 
Acho que não consigo perceber muita influência... Nos meios de comunicação em massa ela não aparece. Não é uma música consumida pela maioria e nem mercadológica. No cinema temos a trilha do filme $\mathrm{O}$ alto da compadecida como exemplo de maior alcance. Acredito ser um marco e ter sido bastante influente, mas, não consigo dizer o quanto e nem como influenciou. No meio acadêmico e instrumental tenho visto uma maior produção e consumo da música armorial. Eu particularmente gosto muito de ouvir. Em mim influencia minhas práticas, como instrumentista e professora, meu olhar pra cultura e música locais, dentre outras coisas... (OUVINTE 24, 2016) - mulher, 24 anos, pernambucana, residente em Pernambuco, musicista.

“Alguns grupos têm colocado instrumentos regionais em suas composições para diferenciar suas músicas. Acredito que seja para voltar às raízes nordestinas ou para chamar atenção pelas sonoridades diferentes" (OUVINTE 25, 2016) - mulher, 26 anos, pernambucana, residente na Paraíba, musicista.

Respostas recebidas em 12 de outubro de 2016:

"Mourão" de Guerra Peixe, continua sendo tocada por todo o mundo (no sábado passado, 08/10/16, a Orquestra Sinfônica de Xalapa - México, que está em turnê pelo Brasil, executou Mourão em sua apresentação em João Pessoa). "Missa Nordestina" de Clóvis Pereira, é interpretada com frequência em Pernambuco, pela Orquestra de Câmara de PE. Muitas vezes foi interpretada também pela Orquestra Sinfônica Jovem do CPM. Na TV, pudemos ouvir a música armorial como parte da trilha sonora da novela "Velho Chico". Podemos apreciar ainda as trilhas sonoras de filmes, como "O Auto da Compadecida" por exemplo. Além de muitos outros. (OUVINTE 26, 2016) - mulher, 27 anos, pernambucana, residente na Paraíba, musicista.

"Sim. A influência do armorial é claramente identificada nas produções de alguns artísticas que preservam a harmonia e poesia do Movimento Armorial" (OUVINTE 27, 2016) - mulher, 35 anos, paraibana, residente na Bahia, não musicista.

A influência que percebo está em algumas obras feitas por compositores que buscam beber um pouco na fonte desse movimento e em grupos musicais (alguns já citados pela pesquisadora) que fazem uso das composições armoriais antigas e modernas (ou até que se dedicam exclusivamente a isso). (OUVINTE 28, 2016) homem, 21 anos, pernambucano, residente em Pernambuco, músico.

Respostas recebidas em 24 de outubro de 2016: "Não percebo muita presença da música armorial especialmente na música popular. Provavelmente eu não perceba por ser mais habituado a ouvir música popular e ela possa se fazer mais presente na música erudita" (OUVINTE 29, 2016) - homem, 24 anos, paulista, residente em Pernambuco, músico.

Muitos músicos atuais que utilizam elementos do folguedo popular e da dança nordestina, inevitavelmente acabam por ter influências desse movimento. Antonio Nóbrega, do Quinteto Armorial, ainda está em atividade hoje em dia, levando esses elementos por estrada a fora (sic). Muitas outras bandas seguiram esse estilo como: Quinteto Violado, Mestre Ambrósio, Chão e Chinelo, Cordel do Fogo Encantado, SaGRAMA. Há de salientar, que algumas pessoas que iniciam bandas hoje em dia podem nem mesmo saber sobre esse movimento, e ser influenciado 
por ele através dessas bandas mais recentes. Nas artes das xilogravuras presentes em todo cordel, que você encontra nas feiras de bairros, tem-se a influência do Movimento Armorial, como incentivador da divulgação dessas artes. (OUVINTE 30, 2016) - homem.

O principal legado da Música Armorial foi criar uma consciência e orgulho da música popular. Não tenho visto muitas bandas que trabalham puramente Música Armorial, mas vejo muitas bandas e artistas que se interessam em por em suas composições elementos da música popular. Muitas vezes essa consciência se dá por influência de bandas que não são do Movimento Armorial, mas que têm influência desse movimento. O Manguebeat é um exemplo de movimento que foi influenciado pelo Movimento Armorial e que influenciou inúmeras outras bandas. Portanto, mesmo indiretamente, a Música Armorial tem influenciado muitas bandas que têm a preocupação de destacar a música e outros elementos da cultura popular dentro do seu estilo musical. Dentro do Rock eu posso destacar algumas bandas onde se é possível ouvir essa influência: Angra, Cangaço, Terra Prima, Hate Embrace. (OUVINTE 31, 2016) - homem, 26 anos, pernambucano, residente em Pernambuco, músico.

Acredito que recentemente pude perceber a influência desse tipo de música em algumas apresentações culturais de determinadas bandas na cidade de Caruaru. Como exemplo, posso citar a banda vencedora do Programa SuperStar da Rede Globo, Fulô de Mandacaru. Em algumas apresentações no programa, a banda usou esses recursos para incrementar sua performance no palco. (OUVINTE 32, 2016) - homem, 37 anos, pernambucano, residente em Pernambuco, não músico.

"Penso que a música armorial seja o resultado de um estilo que abarca características e traços da cultura nordestina. Imagino que parte das composições musicais deste estilo surgem como reflexo e influência de uma vivência no nordeste brasileiro" (OUVINTE 33, 2016) homem, 30 anos, pernambucano, residente em Minas Gerais, músico.

Perceber a influência disso na música popular hoje não acho muito fácil. Até porque, do ponto de vista musical, acho que a estamos num período muito difícil, digamos assim. Agora eu percebo essa tentativa de transformar música em algo erudito, por exemplo, nos shows acústicos. Tanto de artistas populares, quanto de artistas da MPB, muitas vezes do rock. Eu vejo o acústico como uma tentativa realmente de tornar a coisa mais erudita. Recentemente houve um show do grupo carioca $O$ Rappa lá no Instituto Brennand, e a transformação de uma música pesada como a d'O Rappa com instrumentos... (OUVINTE 34, 2016) - homem, 42 anos, pernambucano, residente em Pernambuco.

Não somente o Movimento Armorial, mas a música apresenta como um dos principais objetivos impedir a massificação da cultura brasileira, evitando o consumismo imposto pelos norte-americanos e a mídia em geral. Na atualidade podemos perceber sua influência através da dança, do teatro, da música como por exemplo SaGRAMA, Antonio Carlos Nóbrega, Camerata Armorial, que demonstram em seus espetáculos diversos elementos do Movimento Armorial. (OUVINTE 35, 2016) - mulher, 28 anos, pernambucana, residente em Pernambuco, musicista.

"Posso até conhecer músicas armoriais, mas não sei dizer quais são. Não associo o estilo às músicas pois só conheço o termo "Armorial", não conheço as obras" (OUVINTE 36, 2016) - homem, 36 anos, pernambucano, residente em Pernambuco, músico. 
Respostas recebidas em 30 de outubro de 2016:

Percebo sim traços característicos da música armorial presentes em outras situações, embora fora de contexto seja difícil definir precisamente. Desde o uso do instrumental até escalas modais e ritmos próprios da música armorial, muitos grupos novos utilizam desses pontos em sua música, nem sempre visando esse tipo de relação, eu acho. Acho que o grupo musical da Paraíba "Cabruêra" seria um bom exemplo disso. (OUVINTE 37, 2016) - homem, 25 anos, pernambucano, residente em Pernambuco, músico.

Quem mais ouço de música nordestina, é o mestre Dominguinhos. Vejo o modalismo na música dele. Vejo os ecos da música armorial nos artistas citados acima [explicação que acompanhou o questionário. Artistas citados: Clóvis Pereira, Antônio (Zoca) Madureira, Antonio Nóbrega, Antúlio Madureira, Sérgio Ferraz, SaGRAMA, Quarteto Encore, oQuadro]. Vejo esses ecos no nacionalismo de Guarnieri e de Villa-Lobos também. O grupo Sal da Terra e o saudoso Grupo Instrumentus são bandas que também reverberam o Movimento Armorial interpretando músicas que apregoam o evangelho de Jesus. No quesito improvisão (sic), em jazz, frevo, ou regional, não percebo a ideologia armorial, mas sim o uso dos modos evocados pelo movimento. (OUVINTE 38, 2016) - homem, 32 anos, pernambucano, residente em Pernambuco, músico.

Sim, é possível ver que um movimento deixou um legado expressivo. Escutando artistas como Zé Ramalho, Elba Ramalho, Quinteto Violado, Geraldo Azevedo, Alceu Valença, Antonio Carlos Nóbrega, Maestro Clóvis Pereira, entre outros, é possível perceber influências e muita inspiração no Movimento Armorial. (OUVINTE 41, 2016) - homem, residente em Pernambuco.

Posso perceber esse tipo de influência musical mais nas cidades vizinhas e no interior; por meio da TV quando retrata imagens das cidades do interior do sertão com fundo musical; num quadro de uma pintura com imagens de trabalhadores, pessoas sofridas pelo sol escaldante; pelos contos de cordéis ilustrando a nossa realidade cultural. E esse tipo de música só se escuta ou se vê coisas dessa natureza no nordeste do Brasil, assim eu imagino. Me despertei para pesquisar e saber um pouco mais sobre esse Movimento Armorial (que é nosso) a partir desta pesquisa de mestrado. As vezes ( sic) nos 'fechamos' em aprender ou valorizar mais aquilo que nos chama a atenção (fora do Brasil) e esquecemos que aqui na nossa casa temos uma cultura incrível para ser explorada. (OUVINTE 42, 2016) - mulher, 28 anos, pernambucana, residente em Pernambuco, musicista.

Sim e em diversos modos. Recentemente a novela "Velho Chico" se utilizou da música armorial para identificar e representar uma área e uma cultura sertanejas nordestinas, por exemplo. Creio que quando se quer representar o nordeste culturalmente se inserem músicas em estilo armorial em peças de teatro, propagandas, vinhetas, comerciais de TV e rádio e outros do gênero. Há óperas também que se valem disso, como "O Pescador e Sua Alma". Alguns compositores em Pernambuco compuseram obras eruditas para orquestra, para grupos de câmara e instrumentos solo apropriando-se do armorial, mas também alguns compositores de MPB, em diversas regiões, também se influenciaram deste estilo regionalista. (OUVINTE 43, 2016) - homem, 22 anos, pernambucano, residente em Pernambuco, músico.

Sim, podemos encontrar em alguns grupos pernambucanos que em seus contextos musicais apresentam elementos da música Armorial. Dentre eles citamos o "SaGRAMA" que é um grupo bastante conhecido e que tem apresentado muito bem em suas composições características musicais com influências da música Armorial. Além desse grupo podemos citar o "Quinteto Violado" que ao longo dos anos tem apresentado em seu repertório grande influência da música Armorial, dentre outros. (OUVINTE 44, 2016) - homem, pernambucano, residente em Pernambuco, músico. 
"Sim, dentro dos trabalhos musicais que mexem com fusão de ritmos, principalmente em bandas recifences (sic) pós-Mangue beat. Mestre Ambrósio, por exemplo" (OUVINTE 45, 2016) - homem, 36 anos, pernambucano, residente em Pernambuco, músico.

Muito do que é feito hoje sofre forte influência da música pop e das batidas eletrônicas, mas ainda há bandas e músicos influenciados pela música armorial. Alguns mais do que outros, como por exemplo o SaGRAMA e o Mestre Ambrósio que utilizavam mais elementos da música armorial do que Chico Science e Lenine. Mas ainda assim não é tão fácil perceber essa influência na música feita hoje em dia. (OUVINTE 46, 2016) - mulher, 31 anos, pernambucana, residente em Pernambuco, musicista.

Sim. A música armorial tornou-se paradigmática para a representação musical do Nordeste brasileiro. A obra de Clóvis Pereira, Jarbas Maciel, Egildo Vieira, Capiba e Antônio Madureira é uma referência visível em muita música feita hoje em dia. O aproveitamento do material melódico, harmônico e rítmico nordestino que foi, por assim dizer, "canonizado" pelos compositores do movimento, está presente tanto dentro da música de concerto quanto em alguns grupos de música popular artística. Daqui a algumas gerações, os músicos vão olhar a música armorial e entendê-la de uma forma até melhor do que hoje, porque terão o distanciamento temporal e ideológico para observar essa música. Enxergo a influência da música armorial no trabalho de vários artistas e compositores, como já disse, em música de concerto e na música popular artística. Em Pernambuco, vejo a influência da escola armorial (de maneira bastante expandida) na música dos grupos e solistas ligados ao Conservatório Pernambucano de Música: o violeiro Adelmo Arcoverde, a Orquestra Retratos, o grupo SaGRAMA. Na música dos compositores Paulo Arruda (Cangaço de Vida e Morte), Dierson Torres (Requiem Nordestino), Sandro Guimarães (o disco Guriatã). Eu próprio tenho uma experiência (trilha sonora do espetáculo Cantigas e estórias na terra do sabiá, de Maria Oliveira). Fora daqui, vejo a influência do armorial no trabalho do violeiro Ivan Vilela e dos grupos Anima (São Paulo) e Ilumiara (Belo Horizonte - MG). E também na monumental trilha sonora feita pelo maestro carioca Tim Rescala para a novela Velho Chico, cujo enredo se aproximou da estética dramática de Ariano Suassuna. Esse trabalho do maestro Tim Rescala é de grandiosidade e emoção sem tamanhos. Em paralelo à influência do armorial, vejo alguns propósitos e algumas buscas irmãs na música dos compositores Vital Farias (Taperoá - PB) e Elomar Figueira Mello (Vitória da Conquista - BA). Farias, principalmente na sua Missa dos Agricultores, que se apropria do ritual tradicional da igreja católica para compor uma obra de grande e direta força emotiva (um trecho pode ser ouvido a partir dos 17:00 deste vídeo: <goo.gl/szllMq>). Elomar, em seu projeto recente da composição de óperas e galopes estradeiros (que é o seu nome para suas sinfonias). (OUVINTE 48, 2016) - homem, 27 anos, pernambucano, residindo em Pernambuco, músico.

Seria, talvez um pouco precipitado falar muito sobre o assunto já que estou um pouco limitada no envolvimento e exploração musical ultimamente, mas, sim, alguns compositores ainda buscam explorar esse tipo de música na atualidade, acho que um exemplo é o réquiem de nosso professor Dierson. (OUVINTE 49, 2016) - mulher, 26 anos, pernambucana, residindo em Pernambuco, musicista.

O pouco de música armorial que já escutei foi ou dentro da universidade, porém como já dito na pergunta anterior não tenho contato direto com a música armorial, mas, do pouco que posso perceber ela está muito presente no que faz hoje como o forró, baião, xote, e em grupos que tentam resgatar essa sonoridade tanto de forma tradicional como de forma contemporânea. (OUVINTE 50, 2016). - homem, 21 anos, paulista, residindo em Pernambuco, músico. 
"Sinceramente não muito, com algumas ressalvas de SaGRAMA \& Antonio Nóbrega." (OUVINTE 51, 2016) - homem, 55 anos, pernambucano, residindo em Pernambuco, não músico. "Raramente, pois algumas orquestras ainda conseguem executar as peças Armoriais com certa característica. Alguns pequenos grupos de câmara, orquestras de câmara e sinfônica ainda executam esses tipos de música” (OUVINTE 52, 2016) - mulher, 26 anos, paraibana, residindo na Paraíba, musicista.

Sim. Em trilhas sonoras de filmes, novelas, séries e afins com temática nordestina. Nas composições eruditas contemporâneas de compositores nordestinos e outros que se propõem a usar elementos da música nordestina, sem necessariamente serem originários da região Nordeste do Brasil. Nas composições de artistas de música popular que integram de alguma forma a linguagem erudita às suas obras e produções. Alguns exemplos são o grupo SaGRAMA, a cantora Elba Ramalho. (OUVINTE 53, 2016) - mulher, 23 anos, pernambucana, residindo em Pernambuco, musicista.

Sim, claro. O grande legado, idealizado por ARIANO SUSASSUNA, abraçado pelos compositores BENNY WOLKOFF, CLÓVIS PEREIRA, ANTONIO JOSÉ MADUREIRA, GUERRA PEIXE, CUSSY DE ALMEIDA, JARBAS MARCIEL e CAPIBA foi muito marcante e atuante. A influência foi determinante e partir daí foi estabelecido um gênero musical. Eles nos deixaram como presentes musicais um repertório lindo e fascinante. Gerações de compositores e grupos de música em Pernambuco e no Nordeste entenderam a proposta, e assim, passaram a divulgar e viver "armorialmente", exemplo: Orquestra Armorial de Câmara, Quinteto Armorial, SaGRAMA e outros. As orquestras do Nordeste e do Brasil, sinfônicas ou de câmara, grupos de diversas formações divulgam com muito afinco este belo material. Além de cantores da música popular. Este movimento se estende as artes plásticas, poesia, literatura, teatro, cinema, escultura e arquitetura. (OUVINTE 55, 2016) - homem, 56 anos, paraibano, residindo na Paraíba, músico.

"Sim. Nos músicos guitarristas pernambucanos da atualidade que procuram enfatizar os ritmos da nossa região nordeste." (OUVINTE 56, 2016) - homem, 31 anos, pernambucano, residindo em Pernambuco, músico. "A música armorial permanece viva, percebo através dos concertos, homenagens, trabalhos acadêmicos e novas composições que são difundidos no estado de Pernambuco." (OUVINTE 58, 2016) - homem, 24 anos, pernambucano, residindo em Pernambuco, músico. "Não. Acredito que, se há esta influência, talvez ela esteja mais na música instrumental, que não ouço muito" (OUVINTE 59, 2016) - mulher, 22 anos, pernambucana, residindo em Pernambuco, musicista.

Creio que há sim a influência. Sobretudo no tocante a pessoas e grupos, os quais resgatam a musicalidade mais antiga, digamos assim, das décadas de 70 e 80 . Ainda com cantores como Lenine, Silvério Pessoa, Elba Ramalho, etc. O local, creio que mais na capital e na região metropolitana. Em eventos, festas populares, promovidas no Carnaval e em festas municipais. (OUVINTE 60, 2016) - homem, 27 anos, pernambucano, residindo em Pernambuco, não músico. 
Respostas recebidas em 31 de outubro de 2016: "Muito pouca, apenas em música de tradição popular dessa região. Cavalo marinho, bumba meu boi e alguns grupos instrumentais. Ex; SaGRAMA e Quinteto Violado" (OUVINTE 61, 2016) - homem, 30 anos, pernambucano, residindo em Pernambuco, músico. "Pouca influência na atualidade, a não ser em alguns grupos Pernambucanos" (OUVINTE 62, 2016) - homem, 43 anos, paraibano, residindo em Pernambuco, músico. "De certa forma sim, tanto em performance como em composições, sejam completamente ou apenas em alguns elementos como influência das mesmas. E no caráter de composições de grupos regionais, como SaGRAMA e tantos outros" (OUVINTE 63, 2016) homem, 24 anos, pernambucano, residindo em Pernambuco, músico.

Respostas recebidas em 04 de novembro de 2016: "Pouco. Tenho pouco contato com esse repertório. Não sei explicar" (OUVINTE 64, 2016) - mulher, 33 anos, pernambucana, residindo em Pernambuco, musicista.

Sim. Vejo hoje em dia que a fusão de estilos que acaba gerando outros estilos musicais. Embora eu goste, eu não escuto música armorial, nem vejo esse estilo sendo muito reproduzido na sociedade, então não opino sobre como esse estilo influencia a sociedade como um todo. (OUVINTE 65, 2016) - homem, 24 anos, pernambucano, residindo em Pernambuco, músico.

Influência das manifestações nordestinas não se apresentam, em meu ponto de vista, nas atuais produções musicais populares. Entretanto, posso apontar alguns trabalhos de compositores eruditos nordestinos como Marcos F. M, Adelmo Arcoverde e Paulo Arruda. Músicas como "Cangaço de Vida e Morte" e "Pitombando no Baião" do compositor Paulo Arruda e "Arrecifes Armorialis" do compositor Marcos F. M. Esta última composição apresenta elementos do Movimento Armorial e das correntes minimalistas. (OUVINTE 66, 2016) homem, 30 anos, pernambucano, residindo em Pernambuco, músico.

Creio que a música armorial passa por altos e baixos. Podemos ver uma certa influência nos trabalhos de Antúlio Madureira, SaGRAMA, Antonio Nóbrega, dentre outros. A marca do armorial perpassa tanto aspectos estritamente musicais (melodia, harmonia, instrumentação) quanto textuais (conteúdo e forma de escrita). O grande problema que vejo é a dificuldade de se tomar consciência da necessidade de "atualizar" o discurso. Não estou dizendo que a música armorial está "fora de moda", mas, manter a linguagem composicional estritamente presa aos moldes de quando o movimento surgiu é um risco e pode fazer a música soar meio "clichê". (OUVINTE 67, 2016) - homem, 30 anos, pernambucano, residindo em Pernambuco, músico.

"Na verdade não, não reconheço pelo fato de não haver interesse, aliás, o interesse foi de combater esse movimento" (OUVINTE 68, 2016) - homem, 46 anos, pernambucano, residindo em Pernambuco, músico.

Sim. Cada vez mais vimos alunos e escolas se inspirarem nesse tipo de música. O conservatório Pernambucano, a Escola Técnica Estadual de Criatividade do Recife e a Universidade Federal de Pernambuco por exemplo, vem fazendo apresentações com essas influências. Recentemente tivemos uma obra chamada um Requiem Nordestino para Ariano Suassuna de Dierson Torres professor da UFPE. Essa obra 
fez uma turnê no Mês de Outubro desse ano nas cidades de Nazaré da Mata, Paudalho, Arcoverde, Recife, Caruaru e Gravatá. (OUVINTE 69, 2016) - homem, 31 anos, pernambucano, residindo em Pernambuco, músico.

Sim, são obras que se tem tornado mais acessíveis a um maior público, conseguindo acabar com a distinção dos mesmos. Implantado na temática poética de músicas e na utilização de instrumentos. Estes elementos são relacionados, talvez a problemas socioculturais, expondo uma colaboração enquanto arte de resistência que valoriza a identidade de um povo. (OUVINTE 70, 2016) - homem, 20 anos, paulista, residindo em Pernambuco, músico.

Não sei até que ponto a música armorial influencia nos dias de hoje, mas acredito que tenha seu lugar. Pra ser sincera, só ouço músicas com rabeca e viola em eventos culturais no Recife antigo ou algum outro lugar muito específico. Não consigo imaginar essas músicas sertanejas ou de forró sendo influenciada pelo Movimento Armorial. (OUVINTE 71, 2016) - mulher, 30 anos, pernambucana, residindo em Pernambuco, não musicista.

Sim, bastante. através de transmissões em massa por grupos que vêm conservando isto de geração pra (sic) geração. A mídia também é um grande contribuidor para isso e a tendência é misturar a música cultural com erudita. Mas pra (sic) que isso seja mais enriquecedor é preciso ter a arte concreta para haver significado. (OUVINTE 72, 2016) - mulher, 31, pernambucana, residindo em Pernambuco, musicista.

Sim. Por meio da nova geração de compositores pernambucanos como Nilson Lopes e Paulo Arruda, por exemplo. Escrever músicas vibrantes com acordes marcantes, frases que não perdem estas características mesmo se não tiver uma percussão para acompanhar. Existem mais compositores com esta característica hoje, mas termina sufocado pelo bombardeio da música comercial que atinge de cheio a produção por prazer e a transforma em música comercial. (OUVINTE 73, 2016) - homem, 36 anos, pernambucano, residindo em Pernambuco, músico.

Esse gênero musical, infelizmente não faz parte da minha rotina como músico, mesmo fazendo parte de um grupo musical que toca mensalmente variados gêneros musicais, raramente percebo algo que remeta a Música Armorial. A escuta desse gênero se limita apenas a audição de apresentações ou de DVDs dos grupos musicais citados acima. (OUVINTE 74, 2016) - homem, 35 anos, paulista, residindo em Pernambuco, músico.

"Não consigo distinguir o sonido de uma música Armorial, só conheço o Maestro Spok e consigo identificar devido às utilizações dos instrumentos, se claro, o mesmo toca realmente Armorial" (OUVINTE 75, 2016) - mulher, 23 anos, pernambucana, residindo em Pernambuco, não musicista.

A meu ver é perceptível sim, sobretudo a partir dos trabalhos de grupos como o SaGRAMA, Antonio Nóbrega, Fernando Pintassilgo e Antonio Nóbrega. Seus trabalhos ganharam as massas precipuamente pelas trilhas sonoras, feitas para o teatro e cinema, e alavancadas pelos meios de comunicação das massas como a televisão e a internet. No que diz respeito a contemporaneidade, vejo características desses trabalhos em outros segmentos musicais, como os trabalhos da Spok Frevo Orquestra, Orquestra da Bomba do Hemetério, Orquestra Contemporânea de Olinda, o Coco de Arcoverde e tantos outros grupos da nova geração. Essas influências emergem a partir do uso de elementos característicos como, por exemplo: interação entre música, dança e poesia popular, o uso de instrumentos específicos, o próprio "trato" musical (relação timbrística, orquestração ou arranjo) e etc. Ademais, vejo um distanciamento muito grande dessa música com os meios acadêmicos e, sobretudo, com as escolas de educação básica. Não acredito que ela deveria estar presente nas escolas como doutrina e/ou 
modelo de arte nordestina, porém, como um modelo de expressão válido, haja vista que a música e arte Armorial, em sua totalidade de expressões, poderia, facilmente, ser trabalhada como um instrumento de elo entre a música tradicional nordestina e a música europeia ou música erudita. (OUVINTE 76, 2016) - homem, 28 anos, pernambucano, residindo em Pernambuco, músico.

“Até consigo, mas não de forma abrangente. Pois a mídia, de modo geral, não oportuniza aos ouvintes escutar músicas dos compositores à cima citados, com exceções raras de rádios ou TVs locais do nordeste" (OUVINTE 77, 2016) - homem, 27 anos, pernambucano, residindo no Mato Grosso do Sul, músico.

Necessitaria estar mais presente, pois enquanto Ariano Suassuna estava ativo na Universidade Federal de Pernambuco - local onde surgiu o Movimento Armorial - era visível e perceptível tais ações. Hoje, alguns músicos de Pernambuco que utilizam a Rabeca por exemplo, apresentam o estilo de Música Armorial em seus trabalhos, grande exemplo é a musicista Aglaia Costa, apresentando-se com composições para Rabeca e destacando a Música Armorial. Outro movimento que ainda apresenta características do Movimento Armorial é o Cavalo Marinho, que ainda resiste, mesmo diante de uma massificação cultural sem gostos. (OUVINTE 78, 2016) - homem, 30 anos, pernambucano, residindo no Rio Grande do Norte, músico.

Respostas recebidas em 09 de novembro de 2016:

Com toda certeza há uma grande presença na obra de Ariano Suassuna em "O Auto da Compadecida". Muitas de suas obras estavam cheias dos valores culturais do nordeste. Sem dúvida, ele conseguiu influenciar na música, no teatro e na dança. Na prática, participei de um grupo musical chamado "Vida Nova", eram composições com teor cristão e todas em ritmos e melodias nordestinas, porém, o canto, tinha um certo refinamento e técnica do canto erudita. (OUVINTE 79, 2016) - está sem nome e demais informações. Marcou a opção de músico/a.

"Sim. Eu, particularmente, percebo que temos muitos compositores, dos quais cito o Sérgio Campelo, Antônio Madureira e Clóvis Pereira, que continuam a compor músicas com essa linguagem, ou com influência desta" (OUVINTE 80, 2016) - homem, 32 anos, pernambucano, residindo em Pernambuco, músico.

Atualmente alguns poucos grupos se declaram abertamente influenciados ou mesmo dissidentes do armorial, até porquê, a meu ver, as expressões que atuaram diretamente na concepção deste movimento, a música moura-nordestina, os autos e repentes ainda continuam vivas e permeiam outras expressões artísticas diretamente, sem precisar mesmo da ponte do armorial. Temos o grupo quarteto novo, com o uso de escalas mixolídias e dóricas no universo da música popular, as cantigas e autos de um Elomar, e o cinema que denominaria de "cafuçu", por perceber como uma releitura de trovas pitorescas com personagens típicos regionais. (OUVINTE 81, 2016) - homem, 34 anos, pernambucano, residindo em Pernambuco, músico.

Tive o prazer de tocar com alguns desses Compositores do Movimento, como Zoca Madureira, Clóvis Pereira e Jarbas Maciel, e por vivenciar de perto essa música percebo influência na Música de alguns compositores da nova Geração, Dierson Torres, Paulo Arruda, Dadá Malheiros, Mateus Alves, Sérgio Campelo, Cláudio Moura entre outros. (OUVINTE 82, 2016) - homem, 54 anos, pernambucano, residindo em Pernambuco, músico. 
“Cada dia que passa aumenta os músicos e os trabalhos com a música, e de uma certeza forma o Movimento Armorial influenciou no aumento de trabalhos com o estilo nordestino e com a forma que o movimento trazia" (OUVINTE, 83 2016) - mulher, 26, pernambucana, residindo em Pernambuco, musicista.

\begin{abstract}
Sim, percebo. Embora, eu não veja com bastante frequência a execução de tal estilo pelas mídias. Já tive o prazer de tocar a missa de Clovis Pereira, Cangaço de Vida e Morte de Paulo Arruda e algumas músicas de Luiz Gonzaga voltado mais para público erudito. Já presenciei a música com esse estilo sendo executada em diversos lugares, como: TV, Igrejas, porém muitos mais em Teatros. Ao escutar a Música Armorial me sinto honrado em pertencer a um povo tão rico em tradições, ritmos e timbres diversificados, levando a cultura a partir da Música Armorial a outro patamar. (OUVINTE 84, 2016) - homem, 22 anos, pernambucano, residindo em Pernambuco, músico.
\end{abstract}

Muito pouco se vê deste estilo tão rico na atualidade, as marcas deste tão importante estilo ao qual enriqueceu tanto em nossa cultura ficam vagos no tempo, sentimos sim traços da cultura do mesmo nas músicas do mestre Salustiano e em outros grupos mas que poderíamos ter um ênfase maior penso eu. (OUVINTE 85, 2016) - homem, 37 anos, pernambucano, residindo em Pernambuco, músico.

"Infelizmente, não sinto que a música armorial tenha influenciado nos dias atuais" (OUVINTE 86, 2016) - homem, 29 anos, pernambucano, residindo em Pernambuco, músico. "Não percebi nenhuma influência desse tipo de música. Além de alguns grupos que ainda a praticam, não existe uma circulação ampla do gênero o que, a meu ver, não gera influências significativas" (OUVINTE 87, 2016) - homem, 28 anos, pernambucano, residindo em Pernambuco, músico.

Respostas recebidas em 10 de novembro de 2016:

Sim, em vários segmentos da música como em alguns arranjos de guitarra, violão e até viola utilizados tanto no sertanejo conservador (clássico ou raiz) como no sertanejo universitário sempre associado a uma rítmica mais pulsante e mixada eletronicamente. Consigo notar também na emergente "nova música popular brasileira" que mistura o pop, a boça (sic) nova o samba rock e outros com o instrumental da música clássica trazendo cordas (Violinos, violoncelos), até mesmo Arpas, Trompas (trazendo o drama armorial) a exemplo disso podemos citar alguns trabalhos como O DVD manuscrito de Sandy, o DVD Cartas ao Remetente da Banda Católica Rosa de Saron, o estilo ousado de Tiago Iorc focando no voz e violão num toque feroz mas unitários utilizando de 2 a 3 cordas do violão fazendo o baixo para marcar junto a um canto também pulsante refletindo a característica de "vivência" interiorana de luta, de trabalho, de fuga, de desabafo, de tormento. Uma Artista que vem traçando participações musicais extremamente armoriais é Elba Ramalho, que tem a influência armorial já em sua origem reinventada e ainda assim vem se associando a música clássica em alguns trabalhos mantendo a característica armorial "manual, artesanal, trabalho". Lenine em parceria com Sandy no DVD Manuscrito também com o uso do Tambó. Enxergo o "armorial" em alguns movimentos ROCK, como o artista Paulo Rocha, no seguimento axé (Claudia Leitte DVD acústico Nega Loira), No Artista "genial" Jorge Vercíllo. A introdução "moderna e contemporânea" do Ukulele nos conjuntos musicais brasileiros me remete enquanto "som" muito a razão armorial 
artística a exemplo de Clarice Falcão. (OUVINTE 88, 2016) - homem, 22 anos, pernambucano, residindo em Pernambuco, não músico.

Sim, essa corrente estética musical, apesar de oficialmente ter durado apenas uma década, segundo o próprio Ariano Suassuna, que é um dos principais fundadores do movimento, eu percebo ela muito viva influenciando principalmente compositores que vem da academia, como também grupos camerísticos, que trazem suas contribuições para difusão da mesma através de arranjos e adaptações musicais, sobre peças que permeiam esse universo imenso da música armorial, onde o modalismo nordestino tem destaque e vira uma referência para identificação dessa corrente estética. (OUVINTE 89, 2016) - homem, 33 anos, pernambucano, residindo em Pernambuco, músico.

Acredito que o movimento (musical e artístico) popular nordestino (Pernambucano) tem sido profundamente influenciado pelo Movimento Armorial, posso perceber, bandas com os seguintes instrumentos: rabeca, pífanos, e o cordel inserindo no contexto dos shows. Posso destacar: Marsa, forro no caixa, Adiel Luna e Lirinha (OUVINTE 90, 2016) - homem, 31 anos, pernambucano, residindo em Pernambuco, músico.

\section{Algumas considerações}

Para a pesquisa foram realizadas duas perguntas, uma primeira: "O que é música armorial", e uma outra: "Você consegue perceber a influência desse tipo de música na atualidade? De que maneira? Onde? Como?" Nesse trabalho apresentamos as respostas que recebemos.

Nas diferentes colocações é possível notar que a ideia de representatividade do Nordeste, da busca nas culturas dessa região, é bastante frequente. Mesmo quando os/as ouvintes não sabem explicar o que que é a música armorial, a maioria deles/as sabe que tem uma relação com Nordeste. Isto acontece porque os conceitos que são realizados sobre a música, como afirma Merriam, por si só não são capazes de produzi-la. Eles são traduzidos em comportamentos que, em consequência, vão resultar em sons que são aceitáveis culturalmente como música. Esses comportamentos, relacionados à produção e à organização do som, são divididos por Merriam em quatro tipos: comportamento físico/acústico; comportamento verbal em relação à música/som; comportamento social, que inclui quem produz e quem ouve; e comportamentos que possibilitam ao músico a produção de sons apropriados (MERRIAM, 1964, p. 103).

Nem tudo que foi colocado pelas/os ouvintes está de acordo com o que atualmente entende-se como música armorial. Porém essa noção de Nordeste, que se faz presente na definição da estética que deu e dá origem a esse tipo de música e/ou com sua influência é constante atualmente. Devemos nos atentar, entretanto, que o objetivo do Movimento Armorial 
e de Ariano Suassuna não era criar uma estética artística nordestina, mas nacional, brasileira. Contudo, ao utilizar elementos que já eram vistos como regionais, o armorial acabou sendo regionalizado. E isso é claramente percebido na resposta das pessoas.

Os indivíduos, músicos ou não, que constituem uma sociedade, e mais especificamente que fazem parte de determinadas culturas, desempenham comportamentos que dão significados à música. Embora haja um conceito determinado por um grupo de pessoas, que diz o que é a música armorial, detalhes dessa definição são reconfigurados por aquelas pessoas que compõem a cultura na qual essa música e a música com suas influências estão inseridas. O que se percebe é que quando falam em música armorial frequentemente lhe atribuem um significado que é muito mais amplo que a própria definição primeira dela, buscando explicá-la através de uma sonoridade e uma cultura musical que foi eleita como a representativa da região Nordeste do Brasil.

Esse intercâmbio de características, que acabam recebendo de seus receptores significados diversos, acontece porque "a identidade está conectada com a representação de um ou mais grupos humanos" (MORENO 2015, p. 8). A partir do momento que alguém relaciona a música armorial ao Nordeste e ao mesmo tempo entende que um típico trio formado por uma sanfona - instrumento símbolo da representatividade de um tipo de música do Nordeste -, uma zabumba e um triângulo, passa a ver isso como música nordestina. E muitas vezes essa pessoa pode passar a identificá-las como uma única coisa.

Traços culturais e estéticos que aparentemente se apresentam com uma noção de pertencimento a um determinado grupo podem aparecer em outros grupos como característicos deles. Ao mesmo tempo, esse processo de movimento das características faz com que as pessoas passem a entender que algumas singularidades de um grupo sejam definidoras de um outro.

Bauman, ao se referir às identidades, explica que elas "flutuam no ar", algumas escolhidas por nós mesmos/as, enquanto outras são definidas por aqueles/as que nos rodeiam. Consequentemente, há uma probabilidade considerável de não haver um consenso entre elas, deixando permanentemente em aberto o resultado dessa "negociação" entre as identidades (BAUMAN, 2005, p. 19). O discurso de Bauman refere-se ao indivíduo. Todavia, aplicando-o ao plano musical, o que notamos é que as chamadas identidades musicais estão em movimento e são utilizadas quando e como convêm. O que gera uma espécie de "confusão" na atribuição de determinadas categorias. 
Mas isso também pode ocorrer por conta da compreensão e do encontro dos códigos musicais. Ulhôa (1999, p. 82) explica que, de acordo com Tagg, a música tem unidades de significação, cujas menores são chamadas por ele de musemas. Essas unidades não são especificamente um motivo musical, como é estudado na sintaxe da música, mas algo carregado de significados que está além da unidade somente musical, tendo relações com outros meios para criar seus sentidos. Esses itens, que estão presentes no código musical, aparecem de forma semelhante em diversas músicas, o que permite a realização de comparação entre os "objetos".

A semelhança entre determinados códigos pode levar as pessoas a misturar uns com os outros. No caso, o que notamos é que a chamada música nordestina para concerto, e algumas outras sonoridades que são entendidas e convencionadas como nordestinas, frequentemente têm suas características confundidas com as armoriais. E isso ocorre porque em certa medida alguns musemas estão realmente presentes em ambas ou então são muito semelhantes uns aos outros. Também porque música armorial é, atualmente, parte da música nordestina.

As colocações dos/as ouvintes mostram que os ecos armoriais se misturam em muitos aspectos com outros, havendo frequentemente uma espécie de hibridização entre eles, o que nos impossibilita, em alguns casos, de apontá-los como isto ou aquilo. Embora a definição de música armorial e de suas características esteja bem sedimentada no que o Movimento Armorial definiu, os processos de mudança que ocorrem nas sociedades e nos indivíduos vão gerar um olhar com algumas diferenças sobre estes aspectos, adaptando-os às diferentes realidades.

\section{Referências}

BAUMAN, Zygmunt. Identidade: entrevista a Benedetto Vecchi/Zygmunt Bauman, Tradução Carlos Alberto Medeiros. 5. ed. Rio de Janeiro: Jorge Zahar, 2005.

MERRIAM, Alan. The anthropology of music. Illinois: Northwestern University Press, 1964.

MORAES, Maria. Emblemas da Sagração Armorial: Ariano Suassuna e o Movimento Armorial 1970/76. Recife: Editora Universitária da UFPE, 2000.

MORENO, Jean. Revisiting the concept of national identity In: RODRIGUES, Cristina Carneiro; DE LUCA, Tania Regina; GUIMARÃES, Valéria (orgs.). Brazilian identities: compositions and recompositions. São Paulo: Cultura Acadêmica, 2015.

NATTIEZ, Jean. O modelo tripartite de semiologia musical: o exemplo de La Cathédrale Engloutie, de Debussy. Texto da conferência de Introdução à semiologia musical lida pela primeira vez no II Encontro da ANPPOM. Debates 6, Porto Alegre, p. 7-39, 1987. 
NÓBREGA, Ariana. A música no Movimento Armorial. Dissertação de mestrado em Música. Universidade Federal do Rio de Janeiro, Rio de Janeiro, 2000.

OUVINTE 1. Questionário respondido para a autora. Facebook. Em 24, ago. 2016.

OUVINTE 2. Questionário respondido para a autora. Facebook. Em 4, out. 2016.

OUVINTE 3. Questionário respondido para a autora. Facebook. Em 4, out. 2016.

OUVINTE 4. Questionário respondido para a autora. Facebook. Em 4, out. 2016.

OUVINTE 5. Questionário respondido para a autora. Facebook. Em 4, out. 2016.

OUVINTE 6. Questionário respondido para a autora. Facebook. Em 4, out. 2016.

OUVINTE 7. Questionário respondido para a autora. Facebook. Em 4, out. 2016.

OUVINTE 8. Questionário respondido para a autora. Facebook. Em 4, out. 2016.

OUVINTE 9. Questionário respondido para a autora. Facebook. Em 4, out. 2016.

OUVINTE 10. Questionário respondido para a autora. Facebook. Em 5, out. 2016.

OUVINTE 11. Questionário respondido para a autora. Facebook. Em 5, out. 2016.

OUVINTE 12. Questionário respondido para a autora. Facebook. Em 5, out. 2016.

OUVINTE 13. Questionário respondido para a autora. Facebook. Em 5, out. 2016.

OUVINTE 14. Questionário respondido para a autora. Facebook. Em 5, out. 2016.

OUVINTE 15. Questionário respondido para a autora. Facebook. Em 5, out. 2016.

OUVINTE 16. Questionário respondido para a autora. Facebook. Em 5, out. 2016.

OUVINTE 18. Questionário respondido para a autora. Facebook. Em 6, out. 2016.

OUVINTE 19. Questionário respondido para a autora. Facebook. Em 6, out. 2016.

OUVINTE 20. Questionário respondido para a autora. Facebook. Em 6, out. 2016.

OUVINTE 21. Questionário respondido para a autora. Facebook. Em 6, out. 2016.

OUVINTE 22. Questionário respondido para a autora. Facebook. Em 8, out. 2016.

OUVINTE 23. Questionário respondido para a autora. Facebook. Em 8, out. 2016.

OUVINTE 24. Questionário respondido para a autora. Facebook. Em 9, out. 2016.

OUVINTE 25. Questionário respondido para a autora. Facebook. Em 9, out. 2016.

OUVINTE 26. Questionário respondido para a autora. Facebook. Em 12, out. 2016.

OUVINTE 27. Questionário respondido para a autora. Facebook. Em 12, out. 2016. 
OUVINTE 28. Questionário respondido para a autora. Facebook. Em 12, out. 2016.

OUVINTE 29. Questionário respondido para a autora. Facebook. Em 24, out. 2016.

OUVINTE 30. Questionário respondido para a autora. Facebook. Em 24, out. 2016.

OUVINTE 31. Questionário respondido para a autora. Facebook. Em 24, out. 2016.

OUVINTE 32. Questionário respondido para a autora. Facebook. Em 24, out. 2016.

OUVINTE 33. Questionário respondido para a autora. Facebook. Em 24, out. 2016.

OUVINTE 34. Questionário respondido para a autora. Facebook. Em 24, out. 2016.

OUVINTE 35. Questionário respondido para a autora. Facebook. Em 24, out. 2016.

OUVINTE 36. Questionário respondido para a autora. Facebook. Em 24, out. 2016.

OUVINTE 37. Questionário respondido para a autora. Facebook. Em 30, out. 2016.

OUVINTE 38. Questionário respondido para a autora. Facebook. Em 30, out. 2016.

OUVINTE 39. Questionário respondido para a autora. Facebook. Em 30, out. 2016.

OUVINTE 40. Questionário respondido para a autora. Facebook. Em 30, out. 2016.

OUVINTE 41. Questionário respondido para a autora. Facebook. Em 30, out. 2016.

OUVINTE 42. Questionário respondido para a autora. Facebook. Em 30, out. 2016.

OUVINTE 43. Questionário respondido para a autora. Facebook. Em 30, out. 2016.

OUVINTE 44. Questionário respondido para a autora. Facebook. Em 30, out. 2016.

OUVINTE 45. Questionário respondido para a autora. Facebook. Em 30, out. 2016.

OUVINTE 46. Questionário respondido para a autora. Facebook. Em 30, out. 2016.

OUVINTE 47. Questionário respondido para a autora. Facebook. Em 30, out. 2016.

OUVINTE 48. Questionário respondido para a autora. Facebook. Em 30, out. 2016.

OUVINTE 49. Questionário respondido para a autora. Facebook. Em 30, out. 2016.

OUVINTE 50. Questionário respondido para a autora. Facebook. Em 30, out. 2016.

OUVINTE 51. Questionário respondido para a autora. Facebook. Em 30, out. 2016.

OUVINTE 52. Questionário respondido para a autora. Facebook. Em 30, out. 2016.

OUVINTE 53. Questionário respondido para a autora. Facebook. Em 30, out. 2016.

OUVINTE 55. Questionário respondido para a autora. Facebook. Em 30, out. 2016. 
OUVINTE 56. Questionário respondido para a autora. Facebook. Em 30, out. 2016.

OUVINTE 57. Questionário respondido para a autora. Facebook. Em 30, out. 2016.

OUVINTE 58. Questionário respondido para a autora. Facebook. Em 30, out. 2016.

OUVINTE 59. Questionário respondido para a autora. Facebook. Em 30, out. 2016.

OUVINTE 60. Questionário respondido para a autora. Facebook. Em 30, out. 2016.

OUVINTE 61. Questionário respondido para a autora. Facebook. Em 31, out. 2016.

OUVINTE 62. Questionário respondido para a autora. Facebook. Em 31, out. 2016.

OUVINTE 63. Questionário respondido para a autora. Facebook. Em 31, out. 2016.

OUVINTE 64. Questionário respondido para a autora. Facebook. Em 4, nov. 2016.

OUVINTE 65. Questionário respondido para a autora. Facebook. Em 4, nov. 2016.

OUVINTE 66. Questionário respondido para a autora. Facebook. Em 4, nov. 2016.

OUVINTE 67. Questionário respondido para a autora. Facebook. Em 4, nov. 2016.

OUVINTE 68. Questionário respondido para a autora. Facebook. Em 4, nov. 2016.

OUVINTE 69. Questionário respondido para a autora. Facebook. Em 4, nov. 2016.

OUVINTE 70. Questionário respondido para a autora. Facebook. Em 4, nov. 2016.

OUVINTE 71. Questionário respondido para a autora. Facebook. Em 4, nov. 2016.

OUVINTE 72. Questionário respondido para a autora. Facebook. Em 4, nov. 2016.

OUVINTE 73. Questionário respondido para a autora. Facebook. Em 4, nov. 2016.

OUVINTE 74. Questionário respondido para a autora. Facebook. Em 4, nov. 2016.

OUVINTE 75. Questionário respondido para a autora. Facebook. Em 4, nov. 2016.

OUVINTE 76. Questionário respondido para a autora. Facebook. Em 4, nov. 2016.

OUVINTE 77. Questionário respondido para a autora. Facebook. Em 4, nov. 2016.

OUVINTE 78. Questionário respondido para a autora. Facebook. Em 4, nov. 2016.

OUVINTE 80. Questionário respondido para a autora. Facebook. Em 9, nov. 2016.

OUVINTE 81. Questionário respondido para a autora. Facebook. Em 9, nov. 2016.

OUVINTE 82. Questionário respondido para a autora. Facebook. Em 9, nov. 2016.

OUVINTE 83. Questionário respondido para a autora. Facebook. Em 9, nov. 2016.

OUVINTE 84. Questionário respondido para a autora. Facebook. Em 9, nov. 2016. 
OUVINTE 85. Questionário respondido para a autora. Facebook. Em 9, nov. 2016.

OUVINTE 86. Questionário respondido para a autora. Facebook. Em 9, nov. 2016.

OUVINTE 87. Questionário respondido para a autora. Facebook. Em 9, nov. 2016.

OUVINTE 88. Questionário respondido para a autora. Facebook. Em 10, nov. 2016.

OUVINTE 89. Questionário respondido para a autora. Facebook. Em 10, nov. 2016.

OUVINTE 90. Questionário respondido para a autora. Facebook. Em 10, nov. 2016.

PINTO, Tiago. Som e música: questões de uma antropologia sonora. Revista de Antropologia, v. 44, n. 1. p. 221-286, 2001.

ULHÔA, Martha. Phillip Tagg entrevistado por Martha Ulhôa. Cadernos do Colóquio, p. 81-97, 1999. 